\title{
THE MAN WITH THE SPIDER
}

\section{Escape clause.}

\section{BY MOHAMAD ATIF SLIM}

CC T want out."

"I'm sorry, sir?" Surely she had misheard.

"I want to get out."

The receptionist seemed slightly alarmed. Her eyes stole to the intravenous device on the man's forearm.

"Sir, are you ... sober?" She hesitated. "We do offer a wide range of reversal agents for all classes of pharma, guaranteed not to compromise any subsequent pleasure -"

"But I am sober!" Carusi was dismayed to hear the creeping hysteria in his voice. "Please. I'd like to leave."

"I'm ... not sure if that's possible, sir."

"I signed the contract, I know. But I've changed my mind. Do whatever you want with me, just not this. I can't go through with this. I need to see my wife."

Her eyes again fell on Carusi's arm.

"Please. If you're not able to help, can you get someone who can?"

"I ... Certainly, sir. Please have a seat."

As she retreated into a back room, Carusi gazed anxiously out of the window. The sky was azure over plains of green, and a distant bird soared above snow-flecked mountains. The hyper-realistic projections were designed to deceive; MARTYR was at least 100 kilometres underground.

Like many, Carusi had lapped up the endless supply of stimulants at the beginning. Without sleep, you start to lose count of the days. Time becomes an abstraction of pleasure after pleasure after pleasure. For most, the hour of martyrdom approached with stealth: a brief, errant breeze, then quiet.

But yesterday, Carusi decided to forgo the diafinil. Something gnawed at the back of his mind, a place no pharma could touch. For the first time in perhaps a week, he slept, only to wake up hours later, drenched in sweat. Colomen's face swam across his vision, and he stifled a cry.

That was when panic, that many-legged spider, took residence in the pit of his stomach.

He needed to go home.

How many days had passed since he enlisted?

How many did he have left?

What a fool he was!

He had wanted to lower her mother's medical cap - palliative, then assisted decline, after 60 . Sell the excess. It was the only way they could afford a reproductive

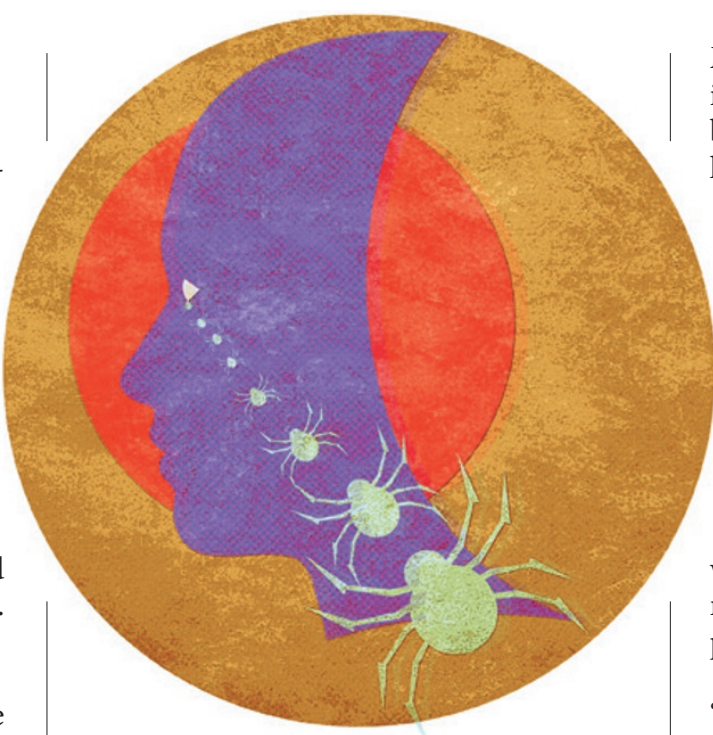

licence before June. They had already missed the sterilization lottery two years in a row. Three would be too lucky.

And Ma didn't need to know.

But Colomen was stubborn. "We'll work, Carusi. We'll earn our licence."

The arguments were long and many, but the last was the worst. Carusi had stormed out. How could Colomen insist on choosing her mother over him? Over their future?

He might have left for hours. He might have got drunk and seen the ad for MARTYR in the subway: "3D-printing for food will saturate in 2 years - for the sake of the children, enlist as a Martyr!"

And he might have, in the heat of the moment, thought it was a good idea.

Martyrdom! For the sake of the child he would never have.

The registrar didn't ask questions, even though Carusi was slurring his words. Martyrdom was a right; in exchange, statesanctioned pleasure for 13 days - boundless, limitless pleasure. And they distort the perception of time too, he'd heard. Make 13 days feel like for ever.

But he'd also heard other things. Rumour orbits MARTYR like flies round a carcass.

The government calls it the solution to over-population: the old for the new, the infirm for the healthy. Cattle are long dead, and oil wells dry; scientists say once the population reaches critical mass, anarchy will prevail - the children will suffer.

Yet, others call it foul. Class-based eugenics, they say. Institutionalized nihilism. They say only the proletariat enlist because society offers them nothing else. That
MARTYR cannot save a corrupt world. That in secret places around the Metropolis, the bourgeoisie scramble to bid at auctions for licences the Martyrs forfeit.

But Carusi didn't care about politics, or much about the world. He had enlisted because he was angry, petty and spiteful.

He knew that now.

"Mr Onnodig?"

Carusi turned with a start. A welldressed man beckoned him into the back room, an expression of grave concern on his face.

"I am very sorry, sir," he began, once they were seated. "I empathize with your predicament, but MARTYR cannot allow for any process reversal. The cogs turn one way."

Inside, the spider gave a malevolent hiss. "But I was unwell!" Carusi pleaded, then added, shamefully: "And inebriated. I was angry with my wife."

"I would like to help, but we have no legal provisions." He handed Carusi a holotablet. "Your contract, sir. Page 254. Clause 537. An Acute Stress Reaction is not tenable grounds for denying a Citizen his right to Martyrdom."

"But what about my rights now?"

"Martyrs have basic rights, but their right to Martyrdom supersedes all else." He paused. "You must understand - MARTYR only works if everyone plays their part. The government compensates the citizen with a commensurate entitlement to pleasure. In turn, you surrender your licence to live."

Carusi felt the spider climb into the hollow of his chest, lodging itself beneath his ribs. Its jaws chittered angrily.

He stared at the opposite wall, unable to find comfort in the gaunt figure reflected in its polished wooden panels.

The girl from earlier approached him with a syringe, her gestures gauche.

"Lotazolam, sir. It can help with anxiety." Carusi ignored her. "Can I call my wife?"

The man shifted uncomfortably in his seat. "This is very... unconventional for us. No one's ever asked to leave." The man seemed to debate internally, glancing at the girl. "But we will spare you five minutes, no more."

They left the man with the spider alone in the room. A minute later, his wife's face flickered onto the holotablet, and Carusi broke down into sobs.

Mohamad Atif Slim is a nomadic Malaysian presently based in Hamilton, New Zealand, the City of the Future, where he works as a secretarial diagnostician. 